\title{
Notes
}

\author{
Bas Jongenelen and Ben Parsons
}

\section{"A Famous and Most Miraculous Prophecy": An Annotated Translation of a Middle Dutch Trickster Poem}

Een schoone ende wonderlijcke prognosticatie (1560) is one of many Dutch texts dealing with the trickster Till Eulenspiegel, known as "Tijl Uilenspiegel" in the Low Countries and "Owlglass" in England. The poem differs from most Eulenspiegel literature in two key respects. First, it treats the figure as a narrator rather than a character, and second, it seems designed for performance rather than simple recital. We offer here an English translation of this remarkable piece, lightly annotated throughout.

\section{The Text and Its Tradition}

The following is the first English translation of the Dutch poem Een schoone ende wonderlijcke prognosticatie (A famous and most miraculous prophecy). This bawdily comic piece was first printed in 1560 by Marie Ancxt, widow of the publisher Jacob van Liesveldt (Rosenwald and Goff 1958). It survives in one copy, now held at the Royal Library of Brussels. Like many early printed works, its author is unknown. What makes this text notable is the unusual treatment of its central theme. The poem belongs to the tradition of Eulenspiegel texts. ${ }^{1}$ Like the best-known example of this literature, Hermann Bote's Till Eulenspiegel ([1515] 2001), it focuses on the trickster Till Eulenspiegel, known in English as "Owlglass."2 The poem is in fact one of several Eulenspiegel tales in Dutch. While the figure may be more readily associated with Saxony, he was no less popular in the Low Countries. The site of his burial is still alleged to be in Belgium, while the first English version of his adventures was print-

\footnotetext{
Bas IONGENELEN teaches Dutch literature at the Fontys University of Professional Education, Tilburg. BEN PARSONS teaches medieval and early modern literature at the University of Leicester and the University of Nottingham Trent.
} 
ed at Antwerp, predating Robert Copland's Howleglas by some four decades (Collier Proctor 1894; Van Bork and Verkruijsse 1985).

However, what distinguishes the Wonderlijcke prognosticatie from other Eulenspiegel texts is its narrative framework. It does not simply recount Eulenspiegel's swindles and exploits. Instead, it uses him as a literary persona. Rather than being simply narrated, Eulenspiegel is himself the narrator of the piece. From the outset, his voice governs the text, as he begins with a gloating celebration of his escapades. During this tribute to himself and his cunning, Eulenspiegel even claims to be immortal: "my hand will never be stayed: / The stink of Owlglass will always pervade" (lines 32-3). ${ }^{3}$ After this boastful prologue, the real business of the text begins. Eulenspiegel puts forward a number of "prophecies," mimicking the almanacs and yearbooks that were popular throughout the early modern period (Salman 1997). As might be expected, these forecasts are clearly fraudulent. Not only are they absurd in themselves, but Eulenspiegel admits that he has no idea "how to write a progno-whatsit," although he "cannot stand by / While others are growing rich" (lines 36-8). The text itself is the swindle here, the trick that Eulenspiegel is playing. In effect, the buyer of the volume becomes a willing dupe of the lord of cheats.

It is important to note that, in spite of its unconventional approach, the poem is a full-blooded Eulenspiegel text. Its use of the figure is by no means superficial or incidental. The text demonstrates a profound connection to the Eulenspiegel tradition as a whole. Most obviously, the powerful strand of satire found in the folk stories also appears in the poem. The same range of targets are ridiculed, as the poem mocks students, women, and merchants. But there is also a similarity of even greater importance here. The Wonderlijcke prognosticatie does not merely echo Eulenspiegel's mockery, but it also makes use of his specific techniques. The key strategies of the text mirror those of Eulenspiegel the trickster. From Goethe onward, readers of the Eulenspiegel stories have noted that the trickster employs one tactic with great regularity. Invariably, he chooses to understand the speech of his victims in its most immediate sense: "all the main jokes of the book are based on the fact that everybody talks in figures of speech and Eulenspiegel understands all this literally" (Goethe 1991:133). A clear example of this tendency occurs in tale 33 of Bote's collection, when an innkeeper informs the trickster that "at this table one eats for 24 pfennigs." In response, Eulenspiegel orders a meal, eats heartily, and demands that his host hand over the stipulated sum "as my wage" (Bote [1515] 2001:66).

In certain contexts, this strategy gains a firmly satirical edge. When Eulenspiegel "exasperates his contemporaries by interpreting everything literally" (Keller 1998:vi), he is demonstrating that all language can be successfully understood in its most immediate sense. He is disregarding subtle or obscure meanings and following those that are most readily accessible. The fact that he prospers from this approach suggests that these obvious senses are in fact superior to the esoteric, or at least of greater practical value. Eulenspiegel thus succeeds in championing meaning that can be understood by anyone. In other words, he is egalitarian in his attitude to language, privileging common forms of knowledge over hidden meanings. When this is applied to the language of professionals, it serves to denigrate them. The craftsmen, scholars, and priests that Eulenspiegel confronts are humbled by his antics. Since he devalues precisely the spe- 
cialized, exclusive knowledge on which their positions rest, he takes their prestige from them. According to him, the best that can be known can be known by anyone; private information is of no importance, and neither is any vocation based on it. Eulenspiegel's literal-mindedness becomes a carnivalesque attack on elitism.

The Wonderlijcke prognosticatie extends this logic to prophecy. The principal joke of the text is that Eulenspiegel "forecasts" events that are clearly inevitable. At one stage he states that one "who stands by the stove the best scraps will win" (line 60), while elsewhere he announces: "The husband will often brand his wife a fool, / And, for his pains, have his hair combed with a stool" (lines 176-7). His prediction for the winter months consists of little more than "it will be cold" (line 156). Eulenspiegel's prophecies only consider what is already obvious. Once again, Eulenspiegel turns away from concealed or obscure knowledge, replacing secrecy with blatancy. Everything he reports is, as Jacob Burckhardt states, "general and intelligible to all" (1990:112). It can thus be seen that the behavior of Owlglass the prophet mirrors that of Eulenspiegel the trickster. The text undermines the claimed insights of prophecy in the same way that the trickster debunks pretensions of wisdom. While the Wonderlijcke prognosticatie is not a series of anecdotes, it has fully adopted the picaro as its mouthpiece, leaving his basic nature intact.

Another point of interest here is that the poem is clearly designed for performance. It has long been known that the Eulenspiegel stories were intended for recital. As Alison Williams (2000) has demonstrated, the notions of audience, performer, and spectacle are firmly embedded in their logic. This is confirmed by Robert Laneham's letter to Humphrey Martin in 1575, in which Laneham describes one "captain Cox," a Warwick mason and part-time entertainer. The Eulenspiegel tales are listed as part of Cox's repertoire: "great ouersight hath he in matters of story ... Fryar Rous, Howleglas, Gargantua, Robin hood ... with many mo then I rehearz heer: I beleeue he haue them all at hiz fingars ends" (Furnivall 1871:28). However, the Wonderlijcke prognosticatie is unusual in openly designating how it should be performed. Certain passages are very clearly written with a particular type of routine in mind. For example, lines 270-1 contain a compressed dialogue: "If you are in Ghent, with your lady fair, / What will she do? Screw! Will she? She will, I swear!" This can only be satisfactorily read as an exchange between an actor and his marot-the sceptre or "bauble" traditionally carried by professional fools (Southworth 2003). Since the marot is typically "responsible" for the most scurrilous or indecent remarks, the passage may be rewritten as follows:

OWLGLASS: If you are in Ghent, with your lady fair, what will she do?

MAROT: Screw!

OwLGLASS: Will she?

Marot: She will, I swear!

Traces of these two roles can be glimpsed throughout the rest of the poem. Their presence explains, for instance, the curious non sequiturs that litter the piece. Such incongruous remarks as "catch this,' said the devil, and let a fart fly" may function as interjections by the marot into the speech of the main narrator (line 169). The poem is evidently a comic monologue, intended for recital by a professional clown. 
Internal evidence gives a few clues about the intended audience for these performances. Most of the material seems to be most appropriate to an urban, middle-class milieu. The majority of the jokes concern towns and townspeople, especially toward the end of the piece, and there are copious references to trade. It also seems likely that the poem was performed as part of Christmas celebrations. Almanacs and prophecies sold in greatest numbers at the year's end; as a result, Eulenspiegel's parody would have the most relevance during Yuletide festivities.

In sum, the Wonderlijcke prognosticatie adds something new to the Eulenspiegel tradition without abandoning it altogether. Ultimately, what the poem demonstrates is that, while Eulenspiegel was making his first appearance in English, his role in Continental literature had expanded, making him into a dramatic persona as well as a protagonist.

\section{Notes on the Translation}

Our translation is based on the edition of Een schoone ende wonderlijcke prognosticatie included in Van Kampen and others' volume (1980:59-79). The line numbers of the translated text follow those of Van Kampen's edition. The original text is heavily embroidered with puns and innuendo: we have endeavored to recreate these wherever possible.

\section{A Famous and Most Miraculous Prophecy,}

\section{Revealed to Drunktor Owlglass}

1 A set of forecasts, wondrous to behold,

That the good Drunktor Owlglass has foretold,

A man most skilled in the fraudster's ways:

Every pint-pot rings out his praise.

5 This volume, most assteemed ${ }^{4}$ in all lands,

Was composed where the famed hospital stands.

Buy, read, laugh. Make sure no word bewilders:

It won't cost you thirteen hundred guilders.

Printed by permission of the court in Antwerp in the

Camerpoortbrugghe

10 in the house named the Shield of Artois, by the widow of Jacob van Liesveldt, Anno MDLX. Signed, P. de Lens.

Owlglass speaks:

I was born just once, but whipped many times,

15 Wrecking father's hopes the first of my crimes.

My life has produced no virtue at all,

But at least my deceits were never small.

From the outset my lies were plentiful:

My adult life was no less eventful,

20 I began to play my famous games then.

And now I won't shit on under three men,

I fart and fog up every man's thought:

If you object, your own honor is nought.

Many wish me dead. This I do not doubt: 
25 But a bad weed is hard to root out.

Some claim I am gone, all rotted away,

Yet Owlglass is alive and tricking today.

Countless condemn me, frown at my acts,

But all have some Owlglass under their hats.

30 An Owlglass may die, another may fade,

But in an instant seven more are made.

Therefore my hand will never be stayed:

The stink of Owlglass will always pervade.

I am an artwork of the highest grade.

\section{The Back-Passage}

How to write a progno-whatsit? I

Haven't a clue. Yet I cannot stand by

While others are growing rich and great,

So I'll do my best to prognosticate.

40 But first I must set forth a foreturd, 5

Like the bite you eat, eyes crusted and blurred,

When you first stagger out of bed at noon.

The children must skip to their parents' tune.

I will declare, in words puerile, half-true,

45 What last year's tomorrows will bring you,

What will occur the day before yesterday:

Secondhand futures aren't hard to survey.

So read with care, lest you make a mistake,

He who sleeps little will spend much time awake.

50 Even if my forecasts at first come to nil,

What doesn't happen now at length no doubt will.

If you want to doubt me, do as you choose,

But when the time comes you'll have no excuse.

I will write about things to freeze your blood,

55 Like spectacles of iron, tin, glass, and wood

That allow you to watch as people flee

Those men who can use their fingers to see.

Be quiet now, foreturd. I will begin:

Next year most girls will prefer to sew, not spin;

60 Who stands by the stove the best scraps will win.

\section{The Lunar Eclipse}

Eclipsus, mippus, kippers, slippers, clippers:

Find me in the tiled house, perched on my tripus,

Thirty-three miles from the house of the snake,

65 About sixteen degrees in size, give or take.

I haven't a clue about needles, pins, knives-

Count it up yourself: I don't know ones from fives.

The eclipse will last till its bottom's at the top,

From when it starts until when it starts to stop.

70 On Saint Bavo's day, fifteen hours before noon

People will realize that their rent is due soon.

This will be a marvel to leave all impressed,

As they ransack every box, pocket, and chest,

Especially at my place-it's always the same. 
"Good God!" says the landlady, though she's to blame.

The eclipse will bring death, disease, much to fear:

Sickness will claim all bellies filled with beer;

Noses will redden, eyes grow dim, hands shake;

Old women's teeth will start to rot and flake.

\section{The Reigning Lords of the Year}

In ascension will be Mars and Venus,

One when the sword reigns; the other, the penis.

In winter three others will take their place:

Monsieurs Dripnose, Chatterteeth, and Blueface.

85 Many at the pawnbroker will plead their case.

\section{The Seasons of the Year}

\section{Spring Comes First}

Spring will push aside the cold winter's gloom

When the leaves and flowers first start to bloom.

90 And then each would-be Venus will sport,

Find herself a suitor, with him cavort,

Speared by love's bolt like a poor piece of game.

It's all "Good day, sir," and "I wish you the same."

All is moonbeams. They bid sadness adieu,

95 But soon that gut will bulge, I swear to you!

Sighs and tears follow, alasses and alacks.

Without pregnancy, girls would live on their backs,

Within seven miles you wouldn't find one maid.

Childbearing, not sin, makes the girls afraid.

100 Ugly wives will find this time even tougher,

Those with handsome husbands will surely suffer

Because the foulest women, as the wise

Already know, have the greenest eyes.

The husbands of these creatures are not fools:

105 They leave their wives and wade in prettier pools. This will set the wife raging, I'm sure you'll find, Screaming: "Where is that pig? I'm out of my mind!" At night he will come home. Both will start to shout. One will screech and shriek; the other will lash out.

110 My vision has yet more details to declare: The wife will say, "You don't need to go elsewhere! I have all you need. This is the last time, lech!" Whoever catches most blows is the worst wretch. These worn-out tales are too much for my ear.

115 The pot boils over. Close the door, my dear.

\section{On Summer}

When spring has gone, just as midday follows morn, Summer will begin. A scorching sun will dawn.

Its warmth will make girls hotter than a forge-

120 They will long to bathe in the froth of Saint George.?

The heat will cause all people to perspire,

Many a furnace will be lit by that fire.

And all will suffer beneath those fierce skies, Especially so when it's time to pay tithes, 
125 Which most will take from the eleventh part

Of their wage. All will cry: "Come! Let the feast start!"

Then we'll go drinking until our stomachs burst:

A bad custom. But, sir, dry bread won't cure thirst. ${ }^{8}$

\section{On Autumn}

130 In autumn the student leaves his books unread To leaf through the boughs of apple trees instead.

The whole of Antwerp will sing out the line: "Step this way, gents, for good cider from the Rhine! Get your cider here! One sniff drives women mad!"

135 Only good bacon will buy an ox, my lad.9 Mass will be held everywhere, with grape and pear And apple juice. A genuine drunkard's fair! They limit their drink-just one pot at a timeBut will soak up the lot. The inn's profits climb.

140 I'll bet the next day you'll find them in their beds, With the cellar-fever drumming in their heads. When their pain gets far too much to endure Quote them the following, a guaranteed cure: When morning brings the drinker pain,

145 As his head shakes and senses fog, It will be to his immense gain To take at least one hair of the dog. ${ }^{10}$ Drunk at night? Lie down. Ill at cock's crow? Drink more. Alexander knew: poison is its own cure.

150 John Poxson, standing on two rotten shanks, Should hop and leap in gratitude and thanks. Adulterers, this will cool your lust for quim.

Booze is only bad for the stork who can't swim.

\section{On Winter}

155 Regarding winter, there's one thing you should Know: it will be cold. So, gather up some wood, And steer clear of water when it starts to freeze. May god bless you, my friend, if you should sneeze. No cows will be seen rutting in the pasture,

160 Fire will be John Ashfarter's new master. Without brushes or paint, wondrous to tell, Rooms will turn shit-colored, as flux works its spell. Winter is one of our most unwelcome guests, Yet Master Ritchy Finefurs couldn't care less.

165 It will no doubt rain, and probably snow, Sleet, hail, and wind, just like twelve months ago. But how nice to eat meat by the fire, where it's dry! "Catch this," said the devil, and let a fart fly.

\section{On Peace and War}

170 Want a war? It's yours. Same if you want a truce. "Boy," calls the mistress, "put that bobbin to use." The opposition of Mars will cause much strife: Venus's conjunction will bring quiet life.

This year will see no one quarrel without talk. 
175 The frog will frequently curse the cruel stork. The husband will often brand his wife a fool, And, for his pains, have his hair combed with a stool. Since this boring, bothersome war's first outbreak ${ }^{11}$ Thirty-two years have passed by, give or take.

180 Soldiers die daily beside the mounted knight: Now, for one man's breeches, seven girls will fight. Good news! I'll ensure my slacks don't lose a thread, For they will lure many ladies to my bed! Fiercely those girls will claw each other's throats!

185 My pants, I hope, will take me beneath their coats. Girls will rip them to shreds! There's no protection! A good, honest wife needs no correction.

\section{On Finances and Investment}

This year will see bumper crops of fruit.

190 Seek to acquire whatever you can loot: Life is good when your food intake is upped. Buy things cheaply, and you won't go bankrupt. Grain will be sold in some measure, I hear tell: You will profit from this if you are paid well.

195 Wheat and oats will be sold in sacks on the street. In Antwerp, biscuits will be baked from buckwheat. "Roll up, roll up! For butter, this is the spot!" Two half-pints will be found in each pint-pot. If the wine harvest is good we'll drink, no doubt:

200 If not, very little will be poured out. How good to be filled with wine, from bowels to teeth! But never leave your jug in front of a thief.

There will be dearth, drought: Nature always deprives Us of everything but bad-tempered old wives,

205 Because Betty Firm-ass and Belle Loose-hair On the fourth page of the Hebrew farce declare: "Listen to my tidings, all men who are wise! An old Beguine will shit out some new advice!"12 I'd rather speak of a pig's tripe and lights.

210 Mistress is at church. Let's try her girl's delights!

On the Phases and Path of the Moon

When the moon is full, it will shine, I vow. Giles Bottoms-up owns one enormous cow: When she's full of milk, she's almost a sphere,

215 But staying that shape does her no good, I fear. When the old moon is through, a new one appears: If you don't believe me, go ask Mr. Pierce.

Pissing on the moon's face is a great strain, Even standing on a spire, perched on the vane.

220 Yet city folk still try it, pricks with no brain.

\section{On the Changing of the Weather}

When the weather is fine, each shrew shuts her face.

If it doesn't change, it will keep the same pace.

If it should alter, and storm clouds appear, 
225 Then rain, hail, and snow will no doubt draw near.

Should the sky turn gray, you shouldn't lose your head: It may not be clouds, but your face that's gray instead. Worse than gray skies is hearing gray men complain. ${ }^{13}$ Many women have the same effect as rain,

230 And send men in sadness to their punchbowls.

Don't tout your eggs, woman. Your basket has holes.

On the Principal Towns

On Antwerp

The Antwerp streets will be foul. The folk will play

235 Games of Kiss-My-Ass every winter's day,

Hiding their faces as they sweep their back gates.

The old custom will rule: many a girl waits

To have her ramparts stormed with a bang and crash.

Her beldame ${ }^{14}$ will say, "That's the way you earn cash."

240 When she has quite worn out her bedfellow,

She will rest her head in a bordello,

And find that her ploughman has sown her with pox.

Where will she go? The clinic, swift as a fox.

All will do the same, but still drink with no heed.

245 "Beso los manos, seinnor de vuestra merceed."15

These ladies look like dames in robes rich and fine.

"Car j'ay veu son robin, ma mere, je veulx Robijn."16

\section{On Brussels}

To the men of Brussels I turn my voice box:

250 Effete they may be, but they eat hens and cocks.

A bad woman must expect a few knocks.

\section{On Louvain}

Vis disputare? Ita. Quid est ita? Don't know. ${ }^{17}$

You are victus. A dish of turds, quid pro quo.

255 Minor students clutter up the back lanes,

With no major scholars to tax their brains

As they creep at night to houses of pleasure,

Pawning their books, their clothes, all their treasure.

Due to their folly, they live on Foolish Hill.

260 Their hats, their cloaks-all will go to foot the bill

When whores fire them up, put them under their spell.

Hey! Isn't mother home? Then I'll say farewell.

\section{On Ghent}

In Ghent it will be noon most of the time,

265 Since the town clock there struggles to chime.

Many act like drunks and fops as they enter

The town, rolling their carts through its center.

The toll collector is a mouthy old slut:

I'll pay her double if she keeps her trap shut.

270 If you are in Ghent, with your lady fair,

What will she do? Screw! Will she? She will, I swear!

"Fart!" cries Satan, drawing a Walloon to his lair. 


\section{On Bruges}

You'll hear: "Beso les manos," "Juan, kiss me slow."18

275 All is in a mess! So I dealt him a blow.

There are many good things to be found in Bruges,

Where there are rich folk, whose purses are huge.

All the girls suffer from raging horn attacks:

One little shove, and they're flat on their backs.

280 The sea pisses, stopping a gnat in its tracks. ${ }^{19}$

\section{On Mechlin}

Try to be prudent, you twits, try not to smirk,

Lest you find yourselves in the dance of Saint Gurck. ${ }^{20}$

When your wife shouts or argues, watch how you tread

285 Or you will find your lodgings in the coal shed.

You, woman, to ensure no rumors spring up,

Always make sure that you fill Saint Gurck's cup:

If any bad wife Gurck's temper rouses,

He'll dance on her bed, steal her old man's trousers.

290 They are unlucky who have wrathful spouses.

On Ypres

"When the giant comes, the dragon tags along":

First Sunday of August, all the bells play that song.21

The clerks of the lottery will stand close by,

295 Ready to dip their fingers into that pie.

The lottery is robbery. That is true-

But if I could buy a good lot, I would do.

No siege could ever cause Ypres any harm,

Since the townsfolk are always chancing their arm.

All the Other Brabantine and Flemish Cities

All will enjoy great peace, I'm glad to report,

Provided that their disputes are settled in court

And not with punches, kicks, and slaps in the street.

Yet some still seek verdicts with their fists and feet,

305 Especially if their lawyer is indiscreet.

\section{Conclusion}

Adieu. Till we next touch, may God keep you:

Pray that when I turn my back, he keeps me too.

FINIS

\section{Notes}

1. A recent overview of the tradition can be found in Hayden-Roy (1991).

2. The most comprehensive collection of Eulenspiegel stories remains Lindow (1978). English translations can be found in Appelbaum (2000) and Bote ([1515] 2001).

3. This may anticipate his famous resurrection in book 5 of Charles De Coster's De legende van Uilenspiegel ([1867] 1922).

4. The original text gives ezele, conflating edele (noble) with ezel (donkey),

5. The original gives protelloghe, combining prologhe (prologue) with protelen (to fart).

6. Saint Bavo's Day falls on October 1. Bavo himself has local significance. A seventh-century Braban- 
tine monk and later a dendrite hermit, he is the patron saint of Ghent and Haarlem. The famous Baafskathedraal is located in the former city.

7. This is one of many proverbial innuendos relating to Saint George, It is not known why sexual connotations should be attached to this particular saint.

8. This appears to be another exchange between the narrator and his marot.

9. The meaning of this line is obscure. It is probably intended to be read as a mock-proverb that, despite its gnomic tone, contains no real insight or wisdom.

10. In the original, het hayr des honts. The idiom has the same meaning in both English and Dutch.

11. A reference to the war with the Duchy of Guelders (1527-28). During this conflict, the Gueldermen caused lasting and widespread damage to Antwerp and the surrounding area. See Limberger (2001).

12. Although the famous lay sisterhoods had declined since their thirteenth-century heyday, some beguinages did linger on into the sixteenth century. In fact, beguine communities were still in existence in the nineteenth century (see Simons 2003).

13. These lines contain an untranslatable pun, based on the double meaning of leelick siet. In Dutch this phrase, which means "looking fierce," can denote both physical ugliness and an overcast sky. Hence the text equates rainy days with unprepossessing men.

14. The original has yrouwe, indicating an older female confidante.

15. "I kiss your hands, my merciful lord" (Spanish).

16. "Because I saw his cock robin, I want to have his cock robin" (French).

17. Apparently, this is a mock student debate in pseudo-academic Latin. It reads: "Do you wish to argue?" "Yes." "What is the nature of 'yes'?"

18. This line seems to represent a scurrilous dialogue between a prostitute and a Spanish nobleman.

19. A reference to a common Dutch proverb that describes any futile gesture or contribution: "Every little helps,' said the gnat, pissing in the sea." The text comically inverts the roles of sea and gnat.

20. Gurck is a fictional saint, whose name is perhaps taken from the town and chief diocese of Carinthia, in modern-day Austria. This passage bears comparison to other mock-hagiographies (see Bayless 1997).

21. The text alludes here to the Thundaghe, a traditional festival held at Ypres in early August. The festival commemorates a military victory of 1383 , in which the city repelled a combined force of Ghentish and English troops, supposedly with the assistance of Onse Lieve Vrouwe vanden Tuin, or Our Lady of the Battlements. The occasion is marked by the ringing of church bells and processions of stilt-walkers. These are the "giants" that Owlglass mentions. On the Thundaghe in the sixteenth century, see Tydeman (2001:536-8).

\section{References Cited}

Appelbaum, Stanley. 2000. Medieval Tales and Stories. Toronto: Courier Dover.

Bayless, Martha. 1997. Parody in the Middle Ages: The Latin Tradition. Ann Arbor: University of Michigan Press.

Bote, Hermann. [1515] 2001. Till Eulenspiegel: His Adventures, trans. and ed. Paul Oppenheimer. London: Routledge.

Burckhardt, Jacob. 1990. The Civilization of the Renaissance in Italy, trans. S. G. C. Middlemore and ed. Peter Burke and Peter Murray. Harmondsworth, England: Penguin.

Collier Proctor, Robert George. 1894. Jan van Doesborgh: Printer at Antwerp. London: Bibliographical Society.

De Coster, Charles. [1867] 1922. The Legend of Ulenspiegel and Lamme Goedzak and Their Adventures Heroical, Joyous, and Glorious in the Land of Flanders and Elsewhere, trans. F. M. Atkinson. London: William Heinemann.

Furnivall, Frederick J. 1871. Captain Cox, his Ballads and Books; or, Robert Laneham's Letter. London: Ballad Society.

Goethe, Johann Wolfgang. 1991. Maxims and Reflections, trans. Elisabeth Stopp and ed. Peter Hutchinson. Harmondsworth, England: Penguin. 
Hayden-Roy, Priscilla A. 1991. Till Eulenspiegel-Transgressions Against Convention: Interpreting the Parasite. Daphnis 20(1):7-31.

Keller, Rudi. 1998. A Theory of Linguistic Signs. Oxford: Oxford University Press.

Limberger, Michael. 2001. No Town in the World Provides More Advantages: Economies of Agglomeration and the Golden Age of Antwerp. In Urban Achievement in Early Modern Europe: Golden Ages in Antwerp, Amsterdam and London, ed. Patrick $O^{\prime}$ Brien, Derek Keene, Marjolein 't Hart, and Herman van der Wee, pp. 39-62. Cambridge: Cambridge University Press.

Lindow, Wolfgang, ed. 1978. Ein kurtzweilig Lesen von Dil Ulenspiegel. Stuttgart: Reclam.

Rosenwald, Lessing I., and Frederick Richmond Goff. 1958. Early Printed Books of the Low Countries: The Lessing J. Rosenwald Collection. Washington, DC: Library of Congress.

Salman, J. 1997. Een handdruk van de tijd: de almanak en het dagelijks leven in de Nederlanden 1500-1700. Zwolle, the Netherlands: Waanders.

Simons, Walter. 2003. Cities of Ladies: Beguine Communities in the Medieval Low Countries 1200-1565. Philadelphia: University of Pennsylvania Press.

Southworth, John. 2003. Fools and Jesters. Stroud, England: Sutton.

Tydeman, William, ed. 2001. The Medieval European Stage, 500-1550. Cambridge: Cambridge University Press.

van Bork, G. J., and P. J. Verkruijsse. 1985. De Nederlandse en Vlaamse auteurs. Weesp, the Netherlands: De Haan.

van Kampen, Hinke, Herman Pleij, Bob Stumpel, Annebel Venmans, and Paul Vriesema, eds. 1980. Het zal koud zijn in 't water als 't vriest: Zestiende-Eeuwse Parodieën Op Gedrukte Jaarvoorspellingen Tekstuitg. Met Inleiding En Commentaar. The Hague: Martinus Nijhoff.

Williams, Alison. 2000. Tricksters and Pranksters: Roguery in French and German Literature of the Middle Ages and the Renaissance. Amsterdam: Editions Rodopi. 